\title{
Influence of Manufacture Process Parameters on Dimensional Stability of Small Blade Castings
}

\author{
Aleš Herman, Irena Kubelková, Ondřej Vrátný, Bohumír Bednář \\ Czech Technical University in Prague, Faculty of Mechanical engineering. Technická 4, 16607 Praha 6. Czech Republic. \\ E-mail: ales.herman@fs.cvut.cz, irena.haskova@fs.cvut.cz, ondrej.vratny@fs.cvut.cz, bohumir.bednar@fs.cvut.cz
}

The production of precise castings by investment casting becomes an increasingly important manufacturing technology and many of isues of this method have to be addressed. This paper deals with evaluation of critical points on wax patterns of small blades. After the casting of certain product, the casting had a deviation from the required dimension. Investigation revealed that the effect on the resulting dimensional deviation is not only the casting process but also the wax pattern injection process itself. The engine and turbine blades are one of the most important parts in turbine or aircraft engine machinery. Casting deformation is an important feature of evaluation the quality of the turbine blade. In order to control the deformation of the turbine blade during investment casting, a novel compensation method based on reverse deformation was proposed in this study. The article investigates and evaluates critical points for deformation of the blades after their production on wax-press machine. In addition, the effect of the pre-deformation preparation and the human factor influencing effect during assembly is evaluated with the main aspect of not machining all surface of small blades.

Keywords: Investment casting technology, Process stability, Thermography, Blades

\section{The suggestion of manufacturig process}

The main idea is to cool down the wax patterns. During the experiments there was only one fixative preparation available, so as to avoid unnecessary downtimes, the cooling time was chosen to be the same as the injection cycle. The nozzle cleaning time was selected with a view to estimating the withdrawal time (to be less). In the meantime, it is only then to remove the blade and hang it behind the lock in the storage bin (it was not ready, so the blades were laid horizontally - which definitely affects the resulting blade precision).

The suggestion of the operating times of the technological process to achieve the highest possible accuracy of the final wax patterns and castings can be seen in Table 1.

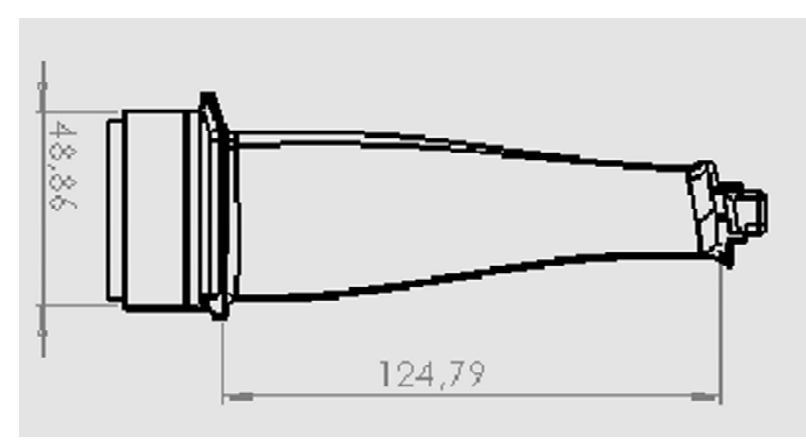

Fig. 1 The preview of the blade with the basic dimension

Tab. 1 Suggestion of operations and recommended times

\begin{tabular}{|l|r|}
\hline Blade injection time: & $120 \mathrm{~s}$ \\
\hline Duration of touchdown: & $60 \mathrm{~s}$ \\
\hline The force of touch: & $3 \mathrm{MPa}$ \\
\hline Nozzle cleaning: & $15 \mathrm{~s}$ \\
\hline Estimated removal time of the pattern (from the moment of lifting, to the complete removal of the casting) & $(15-20) \mathrm{s}$ \\
\hline Estimated time of cutting-off the inlet, visual inspection and insertion into the reformer & $(50-55) \mathrm{s}$ \\
\hline Cooling time & $180 \mathrm{~s}$ \\
\hline Time of removing the fixative preparation from water, removing the blade and laying the blade & $(15-20) \mathrm{s}$ \\
\hline
\end{tabular}

On the basis of the proposed procedure, a program for the injection and adjustment of the machine was prepared (Tab. 1). During the production, the plan is recorded (description of what is done in the given period of time):

- Removal time: the machine starts lifting the upper mold plate, the machine operator with the compressed air blows the dividing plane, opens the mold, removes the blade - the moment of removal is the end time of this phase

- Time to immersion into the water: Cutting off the inlet, removal of large burrs in the dividing plane, visual inspection of the blade, insertion into the reformer, insertion into the water.

- Cooling time: Defined as a press cycle, at this stage the operator checks the mold, freshens through the silicone oil, blows the compressed air, forms the mold (20 - $25 \mathrm{~s})$ and starts to inject the next part.

- Then, the removal time of the flexative preparation was observed: this included removing the flexative preparation from the water, distributing it, removing the blade, and placing the blade into 
the storage position.

- At the same time, the bath temperature was controled, both when inserting the blade reformer into the water and removing it. As a result of the surroundings, the ambient temperature of the pressing station was monitored.

\section{Monitoring the manufacturing process of the wax patterns}

The following conclusions can be drawn from this process:
- The average time of removal the wax pattern was $19.71 \mathrm{~s}$ - which is at the recommended and estimated interval of $(15-20) \mathrm{s}$, the worst time for the first startup blade was $31 \mathrm{~s}$. The second worst was at blade n. 25 and it was 27 s. For illustration, Graph 1 shows the individual times with the recommended removal band. It can be seen that about $40 \%$ of the blades have been removed longer than the recommended removal time, mainly due to the absence of ejectors and the complex removal of the blade from the mold.

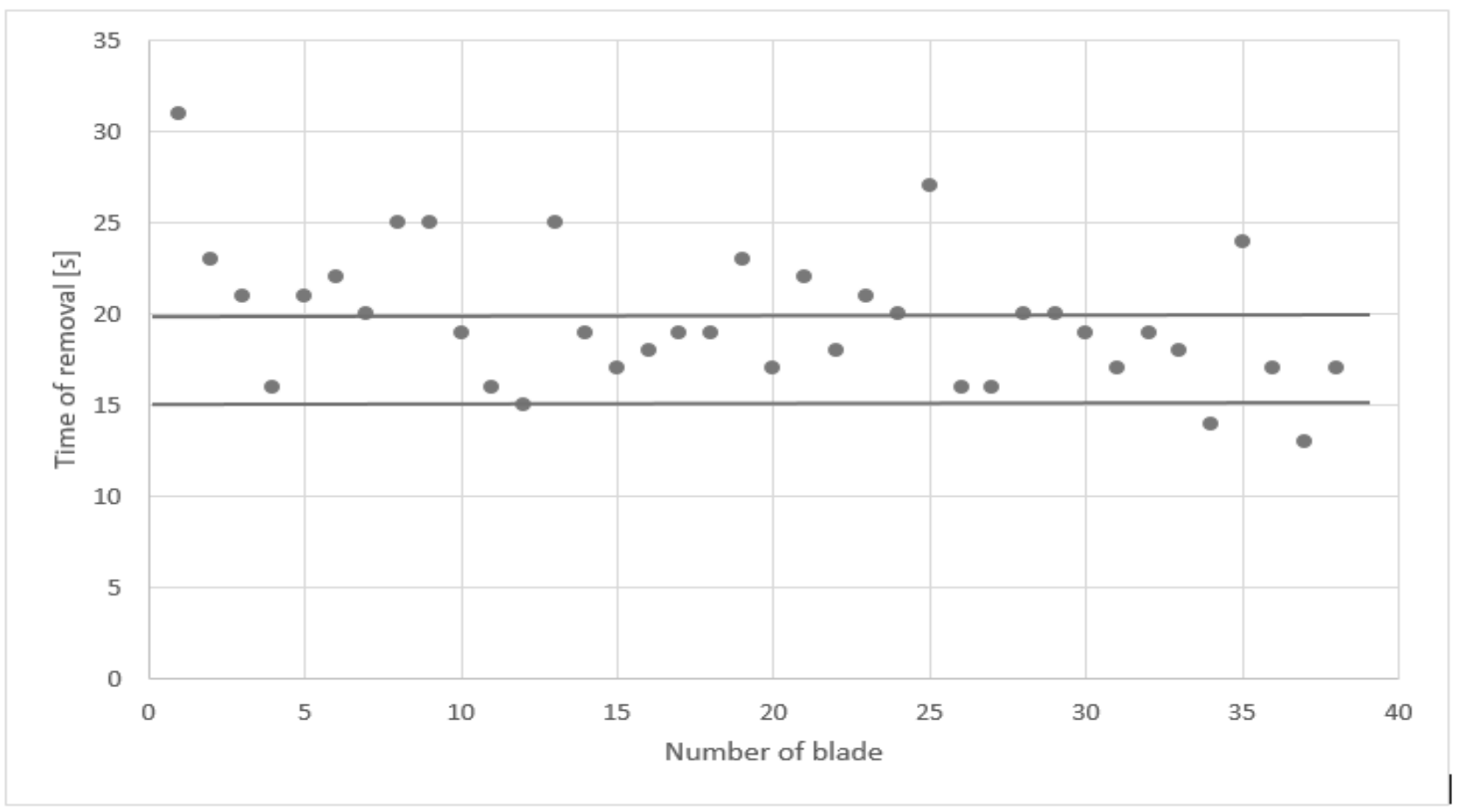

Graph 1 Times of removing the blade (wax patern) from the mold

The same graphs as Graph 1 have been prepared for immersion and placing wax patterns:

- The time to immerse the blade into the water was 58.58 seconds average, which is above the recommended time between 50-55 s. This is caused by the unskilled operator. The most significant deviations in the process are from the beginning of the process - that the process is considered stable since the blade n. 26 is pressed (since then average time of blades n. $26-$ n. 38 was $54.92 \mathrm{~s}$ ).

- The average time of placing the blade on the deck was $21.67 \mathrm{~s}$, which is above the recommended time. After the first 5 pieces, the process stabilized and the remaining pieces had average time about 20 seconds.

From the monitoring of manufacturing process, it is clear that without a mold complemented by ejectors it is not possible to ensure stable production within a very narrow tolerance range. In wax models, as well as in plastic parts, the time spent in the mold has a significant effect on the heat dissipation - if the time is extended by $5-8 \mathrm{~s}$ and the model is extracted with excessive force, the model shows deformations in the order of millimeters. It also shows that damaged models (cracked after removal) have been removed at the upper limit of the recommended interval.

\section{Evaluation of experimental thermograms}

\subsection{Influence of cooling models in water tank}

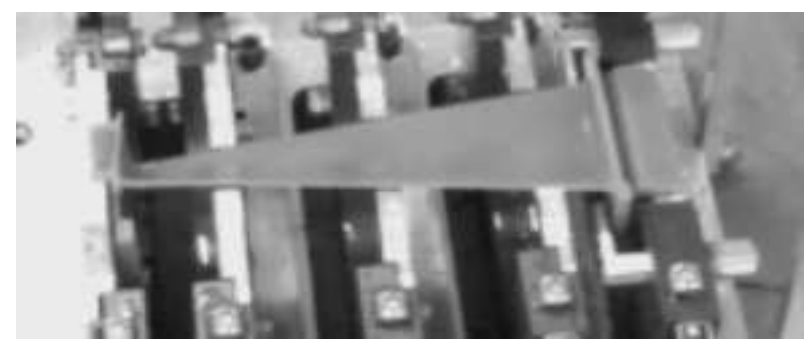

Fig. 2 Wax patern of blade placed in fixative preparation 


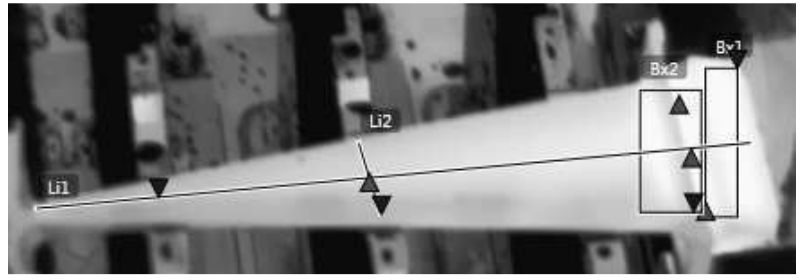

Fig 3 Thermal image with the representation of the places where the temperature was measured. The red and blue arrows feature places with the highest / the lowest temperature in selected areas
The temperature was read from the thermograms of the four models before and after cooling in folowing areas (Fig 2.):

- $\quad$ along the axis of the blade (Li1)

- $\quad$ on the root of blade (Bx1)

- $\quad$ across the blade profile at half height (Li2)

- $\quad$ in the region of the blade base $(\mathrm{Bx} 2)$

In these areas, the minimum and maximum temperatures and the average temperature were monitored.

Tab. 2 Results of temperature measurement of wax patterns when placed in the fixative preparation

\begin{tabular}{|l|c|c|c|c|c|c|c|c|c|c|c|c|}
\hline \multicolumn{1}{|c|}{ Area } & \multicolumn{3}{|c|}{ Along (Li1) } & \multicolumn{3}{c|}{ Root (Bx1) } & \multicolumn{3}{c|}{ Transverse (Li2) } & \multicolumn{3}{c|}{ Base (Bx2) } \\
\hline & $\min$ & $\max$ & avg & $\min$ & $\max$ & avg & $\min$ & $\max$ & avg & $\min$ & $\max$ & avg \\
\hline 1. blade & 25.6 & 37.2 & 29.4 & 25.6 & 37.2 & 34.5 & 25.8 & 29.0 & 27.5 & 26.2 & 39.1 & 32.9 \\
\hline 2. blade & 25.4 & 38.1 & 30.3 & 30.2 & 37.8 & 35.4 & 27.0 & 29.6 & 28.4 & 27.3 & 39.2 & 33.5 \\
\hline 3. blade & 25.4 & 38.8 & 30.9 & 28.6 & 38.6 & 36.2 & 27.1 & 29.7 & 28.5 & 28.5 & 39.6 & 34.5 \\
\hline 4. blade & 29.6 & 39.0 & 32.9 & 29.7 & 38.9 & 36.3 & 26.7 & 30.4 & 29.1 & 28.7 & 39.9 & 35.0 \\
\hline Min. & 25.4 & 37.2 & 29.4 & 25.6 & 37.2 & 34.5 & 25.8 & 29.0 & 27.5 & 26.2 & 39.1 & 32.9 \\
\hline Max. & 29.6 & 39.0 & 32.9 & 30.2 & 38.9 & 36.3 & 27.1 & 30.4 & 29.1 & 28.7 & 39.9 & 35.0 \\
\hline Avg. & 26.5 & 38.3 & 30.9 & 28.5 & 38.1 & 35.6 & 26.7 & 29.7 & 28.4 & 27.7 & 39.5 & 34.0 \\
\hline Avg.dev. & 1.6 & 0.6 & 1.0 & 1.5 & 0.6 & 0.6 & 0.4 & 0.4 & 0.4 & 0.9 & 0.3 & 0.8 \\
\hline
\end{tabular}

Tab. 3 Results of temperature measurement of wax patterns after cooling down

\begin{tabular}{|l|c|c|c|c|c|c|c|c|c|c|c|c|}
\hline \multicolumn{1}{|c|}{ Area } & \multicolumn{3}{c}{ Along (Li1) } & \multicolumn{3}{c|}{ Root (Bx1) } & \multicolumn{3}{c|}{ Transverse (Li2) } & \multicolumn{3}{c|}{ Base $(\mathrm{Bx} 2)$} \\
\hline & $\min$ & $\max$ & avg & $\min$ & $\max$ & avg & $\min$ & $\max$ & avg & $\min$ & $\max$ & avg \\
\hline 1. blade & 13.8 & 25 & 15.8 & 14.9 & 24.9 & 20.5 & 14.1 & 14.6 & 14.3 & 14.1 & 24.9 & 18.3 \\
\hline 2. blade & 13.2 & 24 & 15.7 & 15.9 & 24.7 & 20.7 & 13.8 & 14.2 & 14.0 & 14.0 & 24.9 & 18.8 \\
\hline 3. blade & 13.7 & 24.5 & 15.9 & 15.4 & 24.4 & 20.6 & 14.1 & 14.7 & 14.5 & 15.3 & 23.9 & 18.5 \\
\hline 4. blade & 13.2 & 23.8 & 15.2 & 17.1 & 23.6 & 21.0 & 14.1 & 14.7 & 14.3 & 14.1 & 23.9 & 18.3 \\
\hline Min. & 13.2 & 23.8 & 15.2 & 14.9 & 23.6 & 20.5 & 13.8 & 14.2 & 14.0 & 14.0 & 23.9 & 18.3 \\
\hline Max. & 13.8 & 25.0 & 15.9 & 17.1 & 24.9 & 21.0 & 14.1 & 14.7 & 14.5 & 15.3 & 24.9 & 18.8 \\
\hline Avg. & 13.6 & 24.3 & 15.6 & 15.8 & 24.4 & 20.7 & 14.0 & 14.6 & 14.3 & 14.4 & 24.4 & 18.5 \\
\hline Avg.dev. & 0.3 & 0.4 & 0.2 & 0.7 & 0.4 & 0.2 & 0.1 & 0.2 & 0.1 & 0.5 & 0.5 & 0.2 \\
\hline
\end{tabular}

Tab. 4 The temperature diferences between Tab 1. and Tab. 2

\begin{tabular}{|l|c|c|c|c|c|c|c|c|c|c|c|c|}
\hline \multicolumn{1}{|c|}{ Area } & \multicolumn{3}{|c|}{ Along (Li1) } & \multicolumn{3}{c|}{ Root (Bx1) } & \multicolumn{3}{c|}{ Transverse (Li2) } & \multicolumn{3}{c|}{ Base (Bx2) } \\
\hline & $\min$ & $\max$ & avg & $\min$ & $\max$ & avg & $\min$ & $\max$ & avg & $\min$ & $\max$ & avg \\
\hline 1. blade & 11.8 & 12.2 & 13.6 & 10.7 & 12.3 & 14 & 11.7 & 14.4 & 13.2 & 12.1 & 14.2 & 14.6 \\
\hline 2. blade & 12.2 & 14.1 & 14.6 & 14.3 & 13.1 & 14.7 & 13.2 & 15.4 & 14.4 & 13.3 & 14.3 & 14.7 \\
\hline 3. blade & 11.7 & 14.3 & 15 & 13.2 & 14.2 & 15.6 & 13 & 15 & 14 & 13.2 & 15.7 & 16 \\
\hline 4. blade & 16.4 & 15.2 & 17.7 & 12.6 & 15.3 & 15.3 & 12.6 & 15.7 & 14.8 & 14.6 & 16 & 16.7 \\
\hline Min. & 11.7 & 12.2 & 13.6 & 10.7 & 12.3 & 14 & 11.7 & 14.4 & 13.2 & 12.1 & 14.2 & 14.6 \\
\hline Max. & 16.4 & 15.2 & 17.7 & 14.3 & 15.3 & 15.6 & 13.2 & 15.7 & 14.8 & 14.6 & 16 & 16.7 \\
\hline Avg. & 13.0 & 14.0 & 15.2 & 12.7 & 13.7 & 14.9 & 12.6 & 15.1 & 14.1 & 13.3 & 15.1 & 15.5 \\
\hline Avg.dev. & 1.7 & 0.9 & 1.2 & 1.1 & 1.0 & 0.6 & 0.5 & 0.4 & 0.5 & 0.7 & 0.8 & 0.9 \\
\hline
\end{tabular}

The average drop in surface temperature of wax patterns in individual regions due to cooling was in the range of $14.1 \pm 0.5^{\circ} \mathrm{C}$ (across the blade profile at half height $\mathrm{Li} 2$, which was the coolest in the fixative preparation) up to $15.5 \pm 0.9^{\circ} \mathrm{C}$ (in the area of base).

The comparison of measurement results shows that the cooling of the blades did not change significantly the temperature differences. Across the blade profile at half 
height - Li2, the cooling difference between the highest and the lowest temperature drops in average by $3.0 \pm 0.4$ ${ }^{\circ} \mathrm{C}$ to $0.5 \pm 0.1^{\circ} \mathrm{C}$, consequently on $1 / 6$, but the average temperature deviation 11 along the axis of the blade - Li1, $8 \pm 1.3^{\circ} \mathrm{C}$ was decreased to $10.9 \pm 0.2^{\circ} \mathrm{C}$, it is approximately $8 \%$. In the area of the root, temperature differences decreased from $9.6^{\circ} \mathrm{C}$ to $8.6^{\circ} \mathrm{C}$ on average and in the base area from 11.8 to $10.0^{\circ} \mathrm{C}$.

\section{Evaluation of dimensions on a 3D scan}

For the measurement of deformations, the blades were selected as far as possible to the average values that means blade n. 10 and blade n. 26. There was used 3D Scanning Equipment ATOS Professional. The drawing with dimensional blade requirements can not be published because of customers' requirements.

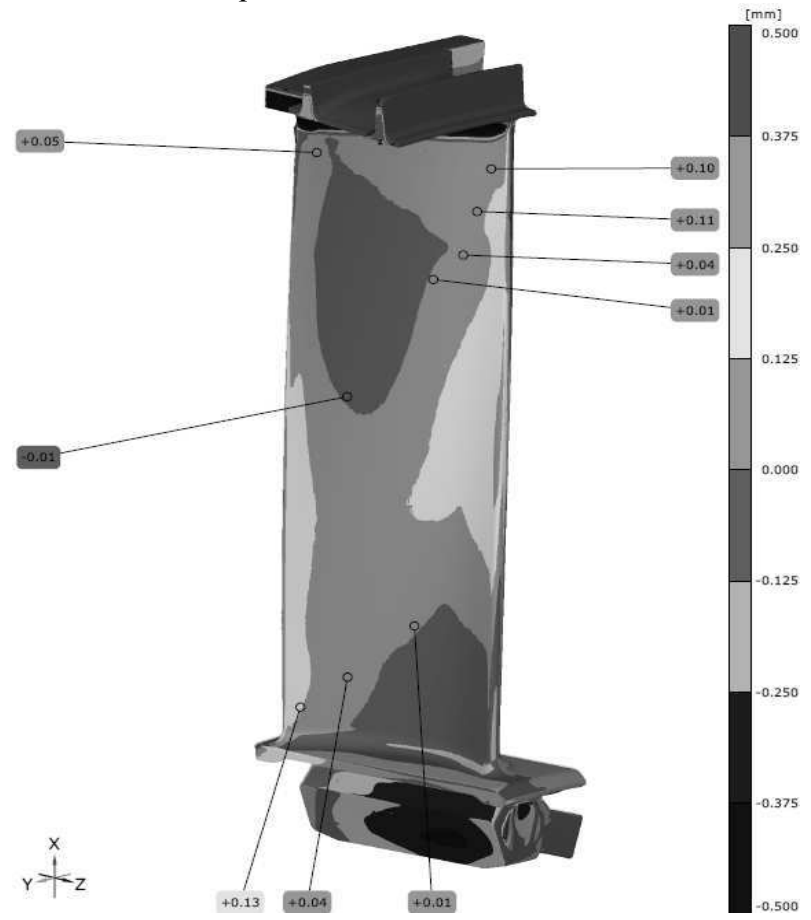

Fig. 4 Color map of deviations from the CAD modelAn example of graphical result of blade $n .10$

The dimensions of both blades meet the required tolerances. It is necessary to realize that a wax pattern that is more than about $1 \%$ larger than the casting was compared.

The worst tolerances are in the bandage where the deflections move to the lower edge of the tolerance. However, the main surfaces of the lock and bandage and the shape of the blade have minimal deviations from the desired shape. A slight problem will be with the tear-off edge of the bandage, where a higher deviation (red image) is due to the blade being rotated during the solidification. However, this deformation is within the allowed tolerances. It can be said that the suggested technology has achieved the required accuracy when controling at the production parameters.

\section{Conclusion}

- Until now, no consideration has been given to the modification of the injection mold - addition of the ejectors

- No cooling unit was designed to remove the heat node

- There was no preparation for hanging the wax patterns for the root.

- Recommended water tank for cooling the water up to temperature of $10^{\circ} \mathrm{C}$ was not designed (it was replaced for sink and ice)

Based on the injection time of wax patterns, the working cycle of the blade was determined for 4 minutes (removal from the mold, removal of the inlet, insertion into the fixative preparation, insertion in the water, starting the next injection, just before the next cycle to take out the fixative preparation, remove the blade and prepare for the next one).

On the thermal image in the Fig. 4 there is in the root area of the blades high temperature - in the production cycle of 4 min can be seen that the root is getting warmer and the whole area is heating up - there is missing a cooling unit here.

The thermogram also shows inappropriate laying position of the blades - it is much better to hang the blade for the root vertically with the bandage heading down.

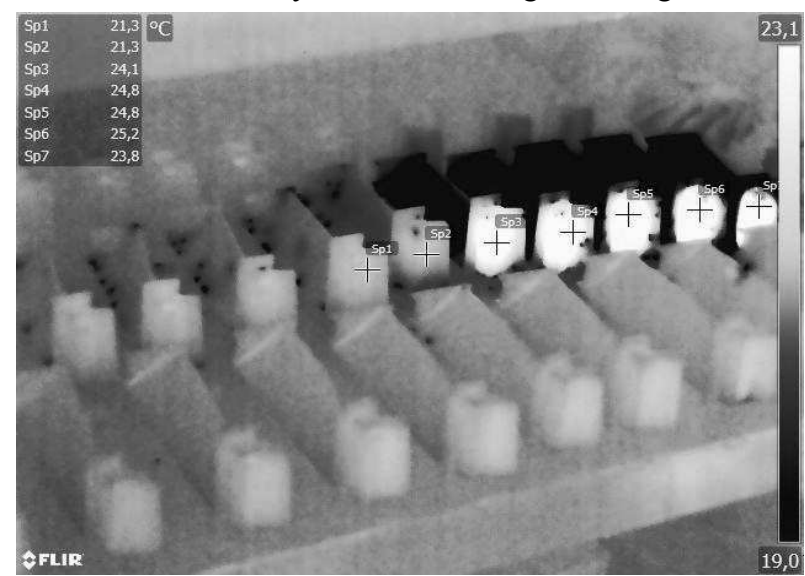

Fig. 5 Thermal image of wax patterns pressed as last

From Chapter 2 of this paper, you can see the time that the blade is removed from the mold - this time ranges from 13 to 31 seconds - again due to the fact that the mold is not filled with ejectors. (manual pulling out of the mold causes a number of more deformations because the whole wax model is still above the temperature when the wax softens - more than $28^{\circ} \mathrm{C}$ ).

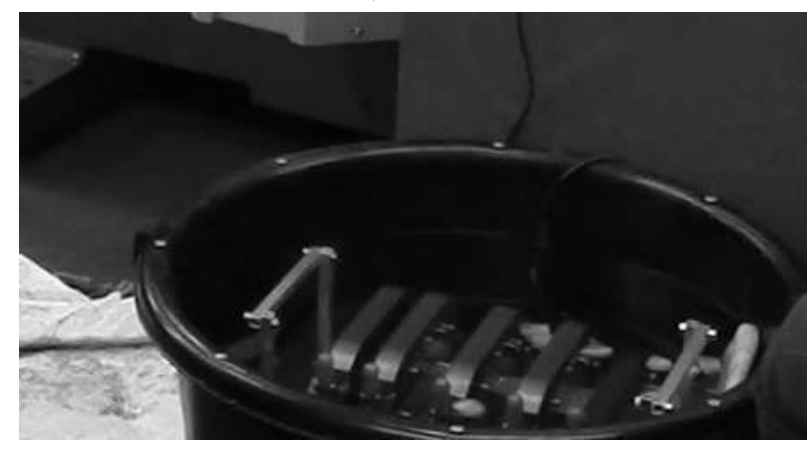

Fig. 6 Temporary cooling bath 
Fig. 5 shows the possibility of cooling the wax patterns. This can be used only in the case of experiments, never during ordinary manufacturing process. Next step is to design cooling bath made of stainless steel with approximate inner dimensions of $(500 \times 800 \times 800) \mathrm{mm}$ and outer with $(100-200) \mathrm{mm}$ larger on each side, which would be connected to cooling device.

\section{Acknowledgement}

This paper was created in cooperation with the company První brněnská strojírna Velká Bíteš, and in the form of an economic contract under the project TRIO No. FV10105, Research on the enhancement of the shape accuracy of wax models for turbocharger blade castings and strain gas turbines.

\section{References}

[1] CONEV M; VASKOVÁ, I. HRABOVČÁKOVÁ, M. (2017). The Influence of Mould Strength on Shrinkage Production for Castings with Different Wall Thickness for Material EN-GJS-400-18LT. (2017). In Manufacturing Technology. Ústí nad Labem. Vol. 17, No. 1, pp 14-18. ISSN 1213-2489.

[2] SUCHÁNEK, A.; LOULOVÁ, M. at all (2017). Use of Infrared Thermography under Laboratory Conditions. (2017). In Manufacturing Technology. Ústí nad Labem. Vol. 17, No. 1, pp 3-7. ISSN 1213-2489.

[3] BENEŠOVÁ, S.; KŘÍŽ, A.; BENEŠ, P. (2018). Analysis of the Joint between Blade and Stator Disc in Steam Turbine. (2018). In Manufacturing Technology. Ústí nad Labem. Vol. 18, No. 3, pp 518-522. ISSN 1213-2489. DOI: 10.21062/ujep/131.2018/a/12132489/MT/18/3/518

[4] VRATNY, O; HERMAN, A \& KUBELKOVA, I (2017). The Application Of Thermographic Diagnostic In Investment Casting Process, Proceedings of the 28th DAAAM International Symposium, pp.1118-1125, B. Katalinic (Ed.), Published by DAAAM International, ISBN 978-3-90273411-2, ISSN 1726-9679, Vienna, Austria DOI: 10.2507/28th.daaam.proceedings. 156

[5] KUBELKOVA, I; HERMAN, A \& VRATNY, O (2017). Evaluation of Critical Places on Wax Patterns of Blades, Proceedings of the 28th DAAAM International Symposium, pp.1126-1135, B. Katalinic (Ed.), Published by DAAAM International, ISBN 978-3-902734-11-2, ISSN 1726-9679, Vienna, Austria DOI: 10.2507/28th.daaam.proceedings. 157

[6] HERMAN, A.; ČESAL, M.: Temperature Stability of the Process of Production of Wax Patterns for Investment Casting Technology, Manufacturing Technology. 2012, 12(12), 108-112. ISSN 1213-2489.

[7] JIANG, R., ZHANG, D., BU, K. et al. (2017). A deformation compensation method for wax pattern die of turbine blade, (2017) 88: 3195. https://doi.org/10.1007/s00170-016-9030-5

[8] WANG, D., HE, B., LIU, S. et al. Int J Dimensional shrinkage prediction based on displacement field in investment casting (2016) 85: 201. https://doi.org/10.1007/s00170-015-7836-1

[9] DONG, YW.; ZHAO,Q.; LI, XI.; LI, XJ. \& YANG, J. (2017). Methodology to develop geometric modeling of accurate drilled cooling holes on turbine blades, Proceedings of the ASME Turbo Expo: Turbine Technical Conference and Exposition, AMER Soc Mechanical Engineers, Three Park Avenue, New York, NY 10016-5990 USA, ISBN:978-0-7918-5091-6

[10] HANCOCK, P. Technical Report : Wax Evaluation. Cambridge, UK : [S.N.], 2011. 24 Quality Control Manual (Summary). [S.L.] : BLAYSON OLEFINES LTD, 200?. $28 \mathrm{~S}$.

[11] HERMAN, A., ČESAL, M., A PÍŠA, V. (2017). Měření Vlastností Voskových Směsí Jako Vstupních Dat Do Databáze Simulačního Software. Strojirenská Technologie. 2014, XIX(1), S. 8-12. ISSN 1211-4162.

[12] HERMAN, A., ČESAL, M., A MIKEŠ, P. (2012). Problematic Of Model And Castings Deformations In Investment Casting Technology. In: ULEWICZ, Robert A BENEŠ, L., Eds. New Trends In The Field Of Materials And Technologies Engineering. Czestochowa: Oficyna Wydawnicza STOWARZYSZENIA MENEDZERÓW JAKOŚCI I PRODUKCJI. 2012, S. 160-177. ISBN 978-83-934225-2-4.

[13] BOND, D.; NISHIKAWA, K. . Investigation Of Wax Expansion. Blayson Technical Lectures. 2002, S. 1-44.Volume 834-836, 2013, Pages 1575 1579,2013 3rd International Conference On Materials And Products Manufacturing Technology, ICMPMT 2013; Guangzhou; China; 25 September 2013 Through $26 \quad$ September 2013; Code 100757

[14] MODUKURU, S.C.-RAMAKRISHNAN, N.SRIRAMAMURTHY, A.M.: Determination Of The Die Profile For The Investment Casting Of Aerofoil-Shaped Turbine Blades Using The Finite-Element Method. Journal Of Materials Processing Technology 58 (1996) 223-226

[15] HORÁČEK, M. - HELÁN, J.: Dimensional Accuracy And Stability Of Investment Casting, 46th Annual Technical Meeting, ICI, 1998, Orlando 